\title{
SCIENTIFIC REPORTS

\section{OPEN Bioefficacy of Rhynocoris longifrons (Stål) (Heteroptera: Reduviidae) against multiple cotton pests under screen house and field conditions}

\begin{abstract}
Kitherian Sahayaraj $^{1 *}$, Subramanian Kalidas ${ }^{1}$ \& Loko Yêyinou Laura Estelle ${ }^{2}$
Rhynocoris longifrons (Hemiptera: Reduviidae) is a generalist predator of many cotton insect pests. The hiding behaviour of this predator, which is one of the key factors of predation success, was investigated under screen house conditions. Moreover, we evaluated its biocontrol potential against Aphis gossypii (Hemiptera: Aphididae), Dysdercus cingulatus (Hemiptera: Pyrrhocoridae), Phenacoccus solenopsis (Hemiptera: Pseudococcidae), and Helicoverpa armigera Hübner (Lepidoptera: Noctuidae) under screen house and field conditions. Results showed that $R$. longifrons life stages preferred to hide under small pebbles in the screen house tests. All the $R$. longifrons life stages showed a biocontrol potential against the four insect pests under screen house conditions. However, their biocontrol potential had not varied in relation to day and night hours. Augmentative releases of $R$. longifrons were carried out for two seasons such as South-west monsoon, 2011 and post-monsoon, 2012. The augmentative release of $R$. longifrons reduced significantly insect pests on cotton. In fact, the release of this predator in cotton fields was capable to reduce the population of $H$. armigera (50\%), P. solenopsis (28\%), D. cingulatus (18.8\%), and A. gossypii (11.8\%) during the rain fed condition (south-west monsoon season). During irrigated condition (post-monsoon season), populations of $D$. cingulatus were reduced by $26 \%$, than P. solenopsis (20.6\%), and A. gossypii (16.8\%). Except ants, no negative impact was reported on other natural enemies present in the cotton field. Significantly higher crop yield and cost benefit ratio was observed in the predator release plots indicating that $R$. longifrons can be used in an integrated pest management program for multiple cotton pests.
\end{abstract}

Cotton (Gossypium hirsutum L., Malvaceae), is an important cash crop throughout the world. However, its production is severely hampered by several abiotic and biotic factors, such as insect attacks that lead to significant yield reduction. Aphis gossypii Glover (Hemiptera: Aphididae) ${ }^{1}$, Dysdercus cingulatus (Fab.) (Hemiptera: Pyrrhocoridae) ${ }^{2}$, Phenacoccus solenopsis Tinsley (Hemiptera: Pseudococcidae) ${ }^{3}$, and Helicoverpa armigera Hübner (Lepidoptera: Noctuidae) ${ }^{4}$ are considered as economically important pests of cotton. Conventional synthetic chemical insecticides are typically extensively used causing significant side effects including pesticide resistance $^{5}$ as well as having many ecological and biological impacts ${ }^{6}$.

Members of Reduviidae are abundant predators of many economically important insect pests ${ }^{7-9}$. Reduviids are common in cotton agro-ecosystems ${ }^{10,11}$. However, they often fail to colonize fields to provide effective control of the pests. In such a situation, augmentative biological control can be an important approach to protect the cotton. Augmentative biological control is practiced worldwide with more than 150 species of natural enemies now commercially available ${ }^{12}$. However, generalist predators, particularly predatory bugs, have been largely ignored for augmentative biological control of cotton pests ${ }^{13,14}$.

A number of researches investigated the impact of augmentative release of various reduviids against a wide variety of insect pest's world-wide ${ }^{15-20}$. However, in cotton growing regions of India, biocontrol potential of reduviids have not fully explored. Native reduviid predator species have shown good predation against many insect pests $^{8,21}$. One of the most important genera of Reduviidae, as well as widely present in many agro-ecosystems is Rhynocoris Hahn (Hemiptera: Reduviidae) ${ }^{9}$. Specifically, Rhynocoris longifrons (Stål) is a general predator of

${ }^{1}$ Crop Protection Research Centre, Dept. of Zoology, St. Xavier's College, Palayamkottai-627 002, Tamil Nadu, India. ${ }^{2}$ Ecole Nationale Supérieure des Biosciences et Biotechnologies Appliquées (ENSBBA), Université Nationale des Sciences, Technologies, Ingénierie et Mathématiques (UNSTIM), BP 14, Dassa, Benin. *email: ksraj48@gmail.com 


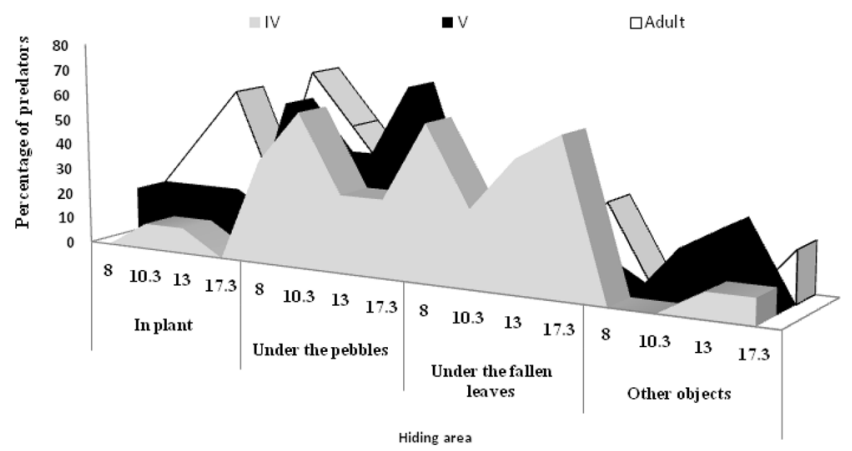

Figure 1. Hiding area of R. longifrons fourth and fifth stadium nymphs and adult (male and female) (\%) released from morning 6 a.m., 8.30 a.m., 11.00 a.m., and to 3.30 p.m. and observation made in 2-hours intervals under screen house conditions.

\begin{tabular}{|c|c|c|c|c|}
\hline \multirow[b]{2}{*}{ Predator life stages } & \multicolumn{4}{|c|}{$\begin{array}{l}\text { Observed percentage of predator life stages in different hiding areas } \\
(\text { Mean } \pm \text { SE) }\end{array}$} \\
\hline & In plants & $\begin{array}{l}\text { Under the } \\
\text { pebbles }\end{array}$ & $\begin{array}{l}\text { Under the fallen } \\
\text { leaves }\end{array}$ & Other objects \\
\hline Fourth instar & $5.0 \pm 1.9 \mathrm{c}$ & $40.0 \pm 3.0 \mathrm{~b}$ & $50.0 \pm 7.0 \mathrm{a}$ & $5.0 \pm 1.9 \mathrm{c}$ \\
\hline Fifth instar & $17.5 \pm 2.5 \mathrm{~b}$ & $52.5 \pm 4.5 \mathrm{a}$ & $15.0 \pm 2.9 \mathrm{c}$ & $12.5 \pm 2.5 \mathrm{~d}$ \\
\hline Adults (male + female) & $35.0 \pm 9.5 b$ & $45.0 \pm 3.5 \mathrm{a}$ & $15.0 \pm 3.0 \mathrm{c}$ & $5.0 \pm 2.0 \mathrm{~d}$ \\
\hline
\end{tabular}

Table 1. Hiding location selection (\%) of $R$. longifrons life stages released under screen house conditions $(n=10)$. Percentage followed by different letters within the same line is significantly different at 0.05 level as determined by the SNK test.

many insect pests in cotton fields such as: Hemiptera [A. gossypii, D. cingulatus, P. solenopsis ${ }^{22}$, Clavigralla gibbosa Spinola ${ }^{23}$ and, Nezara viridula Linnaeus ${ }^{24}$; and Lepidoptera [H. armigera and, Spodoptera litura Fab. ${ }^{24}$.

Many reduviid predators possess either morphological adaptive characters ${ }^{25}$ or behavioural adaptive features ${ }^{26}$ including hiding ${ }^{27}$ to successfully capture and feed the preys'. Shelter provisioning with pieces of clay pots and stones in cotton field enhanced reduviids population and increased cotton production ${ }^{21}$. To date, specific information on the predatory behaviour and biological control potential of $R$. longifrons against any pests under field conditions has not been widely reported. The predator can exhibit a variety of necessary adaptations for predation as well as survival ${ }^{28}$. One such important adaptation is a hiding behavior, either to escape from natural enemies and/or to find shelter. This hiding behavior, referred to as anti-predator behaviour ${ }^{29}$ has not been studied with reduviid predators. Moreover, Ambrose ${ }^{30}$ reported that reduviid predators of the subfamily Ectrichodiinae are diurnal, whereas Peiratinae and Emesinae are nocturnal. To date, however, no systematic study has been made of the feeding potential of these predatory $R$. longifrons in relation to day and night hours. Therefore, we conducted a series of studies to assess their possible integration in an augmentative biological control program for cotton pests in Tamil Nadu, India. The specific objectives of this study were to: 1) understand $R$. longifrons hiding behaviour under open field conditions, 2) evaluate their biocontrol potential in relation to day and night hours, 3) test their efficacy in an augmentative release program under field conditions for two seasons, and 4) estimate the cost benefit ratio and percent avoidable loss.

\section{Results}

Hiding behaviour of the predator under screen house. The hiding behaviour of $R$. longifrons revealed that the percentage of predator adults hiding under pebbles was higher at 6 a.m. $(F=42.53 ; \mathrm{df}=3 ; P<0.000)$ and 10.30 a.m. $(F=8.60 ; \mathrm{df}=3 ; P<0.05)$ than other hiding places (Fig. 1). As day light increased, the predator moved under the plants $(F=41.60 ; \mathrm{df}=3 ; P<0.005)$ and then moved either under pebbles $(F=8.63 ; \mathrm{df}=3$; $P<0.05)$ or under the fallen leaves $(F=8.62 ; \mathrm{df}=3 ; P<0.05)$ for hiding. Fifth-instar reduviids preferred to hide under pebbles $(F=42.63 ; \mathrm{df}=3 ; P<0.0005)$, whereas fourth-instar $(F=8.60 ; \mathrm{df}=3 ; P<0.05)$ predator first hid under fallen leaves and latter moved into pebbles, again left the place and returned to the fallen leaves $(F=8.61$; $\mathrm{df}=3 ; P 0.05)$ to hide (Table 1 ).

Biocontrol potential of $\boldsymbol{R}$. longifrons in relation to day and night hours. Rhynocoris longifrons life stages significantly consumed more P. solenopsis $(\mathrm{F}=32.563, \mathrm{df}=1, \mathrm{p} \leq 0.000)$ and A. gossypii adults $(\mathrm{F}=6.696$, $\mathrm{df}=1, \mathrm{p} \leq 0.05)$, D. cingulatus nymphs $(\mathrm{F}=49.439, \mathrm{df}=1, \mathrm{p} \leq 0.000)$, and $H$. armigera larvae $(\mathrm{F}=40.119, \mathrm{df}=$ $1, \mathrm{p} \leq 0.000)$ compared to the control category. No significant differences in the predation rate of $R$. longifrons life stages was recorded on A. gossypii $(\mathrm{F}=1.022, \mathrm{df}=23, \mathrm{p} \geq 0.05)$, D. cingulatus $(\mathrm{F}=1.410, \mathrm{df}=23, \mathrm{p} \geq 0.05)$, P. solenopsis $(\mathrm{F}=0.794, \mathrm{df}=23, \mathrm{p} \geq 0.05)$, and $H$. armigera $(\mathrm{F}=1.092, \mathrm{df}=23, \mathrm{p} \geq 0.05)$ during dawn hours. Similarly, there was also not much significant difference in the activity of $R$. longifrons life stages on $D$. cingulatus $(\mathrm{F}=0.667, \mathrm{df}=23, \mathrm{p} \geq 0.05)$, P. solenopsis $(\mathrm{F}=0.426, \mathrm{df}=23, \mathrm{p} \geq 0.05)$, H. armigera $(\mathrm{F}=2.037, \mathrm{df}=23$, 


\begin{tabular}{|c|c|c|c|c|c|}
\hline \multirow[b]{2}{*}{ Pest species } & \multirow{2}{*}{$\begin{array}{l}\text { Stage of } \\
\text { predator }\end{array}$} & \multicolumn{2}{|c|}{$\begin{array}{l}\text { Predator releasing time } \\
(\text { mean } \pm \text { SE })\end{array}$} & \multirow[b]{2}{*}{ Total mean } & \multirow{2}{*}{$\begin{array}{l}\text { Anova between dawn } \\
\text { and dusk releases }\end{array}$} \\
\hline & & Dawn hours & Dusk hours & & \\
\hline \multirow{4}{*}{ A. gossypii } & Third instar & $0.83 \pm 0.31 \mathrm{a}$ & $0.50 \pm 0.34 \mathrm{a}$ & $0.67 \pm 0.22 b$ & \\
\hline & Fourth instar & $0.25 \pm 0.17 \mathrm{a}$ & $0.50 \pm 0.31 \mathrm{a}$ & $0.38 \pm 0.18 \mathrm{ab}$ & $\mathrm{Df}=1$ \\
\hline & Fifth instar & $0.28 \pm 0.18 \mathrm{a}$ & $0.00 \pm 0.00 \mathrm{a}$ & $0.14 \pm 0.09 \mathrm{a}$ & $\mathrm{F}=0.316$ \\
\hline & Adult & $0.05 \pm 0.05 a$ & $0.11 \pm 0.11 \mathrm{a}$ & $0.08 \pm 0.06 \mathrm{a}$ & $\mathrm{P}=0.575$ \\
\hline \multirow{4}{*}{ D. cingulatus } & Third instar & $0.25 \pm 0.17 \mathrm{a}$ & $0.33 \pm 0.10 \mathrm{a}$ & $0.29 \pm 0.09 a$ & \\
\hline & Fourth instar & $0.17 \pm 0.10 \mathrm{a}$ & $0.25 \pm 0.11 \mathrm{a}$ & $0.21 \pm 0.07 \mathrm{a}$ & $\mathrm{Df}=1$ \\
\hline & Fifth instar & $0.33 \pm 0.08 \mathrm{a}$ & $0.44 \pm 0.14 \mathrm{a}$ & $0.39 \pm 0.08 \mathrm{a}$ & $F=0.216$ \\
\hline & Adult & $0.49 \pm 0.9 \mathrm{a}$ & $0.72 \pm 0.10 \mathrm{a}$ & $0.61 \pm 0.11 \mathrm{a}$ & $\mathrm{P}=0.145$ \\
\hline \multirow{4}{*}{ H. armigera } & Third instar & $0.41 \pm 0.15 \mathrm{a}$ & $0.67 \pm 0.16 \mathrm{a}$ & $0.54 \pm 0.11 \mathrm{a}$ & \\
\hline & Fourth instar & $0.50 \pm 0.18 \mathrm{a}$ & $1.08 \pm 0.35 \mathrm{a}$ & $0.79 \pm 0.21 \mathrm{a}$ & $\mathrm{Df}=1$ \\
\hline & Fifth instar & $0.55 \pm 0.14 \mathrm{a}$ & $0.38 \pm 0.13 a$ & $0.47 \pm 0.09 \mathrm{a}$ & $\mathrm{F}=0.013$ \\
\hline & Adult & $0.88 \pm 0.13 \mathrm{a}$ & $0.49 \pm 0.20 \mathrm{a}$ & $0.68 \pm 0.13 a$ & $\mathrm{P}=0.909$ \\
\hline \multirow{4}{*}{ P. solenopsis } & Third instar & $0.91 \pm 0.15 \mathrm{a}$ & $1.00 \pm 0.22 \mathrm{a}$ & $0.96 \pm 0.13 \mathrm{a}$ & \\
\hline & Fourth instar & $1.00 \pm 0.28 \mathrm{a}$ & $0.75 \pm 0.17 \mathrm{a}$ & $0.87 \pm 0.13 \mathrm{a}$ & $\mathrm{Df}=1$ \\
\hline & Fifth instar & $0.65 \pm 0.26 \mathrm{a}$ & $0.61 \pm 0.23 \mathrm{a}$ & $0.63 \pm 0.17 \mathrm{a}$ & $\mathrm{F}=0.028$ \\
\hline & Adult & $0.82 \pm 0.25 a$ & $0.82 \pm 0.32 \mathrm{a}$ & $0.82 \pm 0.19 \mathrm{a}$ & $\mathrm{P}=0.867$ \\
\hline
\end{tabular}

Table 2. Biocontrol potential of $R$. longifrons third, fourth and fifth stadium and adult (male and female) against $A$. gossypii, D. cingulatus, $H$. armigeraand P.solenopsisin relation to dawn and dusk hours (Mean $\pm \mathrm{SE}$ ). Percentages followed by different letters within the same line are significantly different at 0.05 level as determined by the Student-Newman-keuls test.

$\mathrm{p} \geq 0.05)$, and A. gossypii $(\mathrm{F}=1.098, \mathrm{df}=23, \mathrm{p} \geq 0.05)$ during the dusk hours. A similar trend was observed when compared predation rate between dawn and dusk hours of $R$. longifrons life stages on the four preys species (Table 2). When we considered total predation rate (dawn and dusk hours), no significant difference of predation rate was observed between $R$. longifrons life stage when feeding on $D$. cingulatus $(\mathrm{F}=1.422, \mathrm{df}=47, \mathrm{p} \geq 0.05), P$. solenopsis $(\mathrm{F}=1.081, \mathrm{df}=47, \mathrm{p} \geq 0.05)$, and H. armigera $(\mathrm{F}=0.839, \mathrm{df}=47, \mathrm{p} \geq 0.05)$. However, A. gossypii was significantly consumed more preys by predator third-instar $(\mathrm{F}=3.017, \mathrm{df}=47, \mathrm{p} \leq 0.05)$.

Bioefficacy of the predators under cotton field conditions. In the cotton fields, when the total number of insect pests was considered, the most predominant insect pests were A. gossypii (81\%), P. solenopsis (10\%), $D$. cingulatus (6\%), and $H$. armigera (3\%), during rain fed condition. However, during irrigated condition, the predominant insect pest was P. solenopsis (60.2\%), A. gossypii (32.8\%) and D. cingulatus (8.2\%). Therefore, we mainly concentrated on these pests throughout our observations. A significant reduction in A. gossypii population was observed in $R$. Longifrons-released plots compared to control after the first $(\mathrm{F}=58.571, \mathrm{df}=299, \mathrm{p} \leq 0.000)$ and second $(\mathrm{F}=22.415, \mathrm{df}=299, \mathrm{p} \leq 0.000)$ predator releases during south-west monsoon (Table 3). Yet, during the post-monsoon season a significant reduction in A. gossypii population was observed in R. Longifrons-released plots after the first $(\mathrm{F}=22.761, \mathrm{df}=299, \mathrm{p} \leq 0.0005)$ and third $(\mathrm{F}=5.596, \mathrm{df}=299, \mathrm{p} \leq 0.05)$ predator releases. During the rain fed condition, significant reduction of $D$. cingulatus $(\mathrm{F}=6.951, \mathrm{df}=249, \mathrm{p} \leq 0.05)$ and $P$. solenopsis $(\mathrm{F}=32.147, \mathrm{df}=299, \mathrm{p} \leq 0.0005)$ populations were recorded respectively during the first and third releases of $R$. longifrons life stages. A significantly lower incidence of $H$. armigera $(\mathrm{F}=19.930, \mathrm{df}=299, \mathrm{p} \leq 0.000)$ was reported only during the first release of $R$. longifrons life stages.

During the irrigated condition, a low D. cingulatus population appeared in cotton fields after the first release of $R$. longifrons life stages (Table 3). However, no significant reduction of $D$. cingulatus population $(\mathrm{F}=0.000$, $\mathrm{df}=299, \mathrm{p} \geq 0.05)$ was observed in $R$. Longifrons-treated plots compared with the control. Similarly, during post-monsoon season no significant reduction of $P$. solenopsis population was observed after the first $(\mathrm{F}=0.020$, $\mathrm{df}=299, \mathrm{p} \geq 0.05)$, second $(\mathrm{F}=0.000, \mathrm{df}=299, \mathrm{p} \geq 0.05)$ and, third $(\mathrm{F}=1.198, \mathrm{df}=299, \mathrm{p} \geq 0.05)$ releases of the predator life stages. When we take in account the total mean population after all three-predator releases, there was a significant reduction of $A$. gossypii $(\mathrm{F}=41.908, \mathrm{df}=899, \mathrm{p} \leq 0.000)$, P. solenopsis $(\mathrm{F}=4.949, \mathrm{df}=899, \mathrm{p} \leq 0.05)$, and $H$. armigera $(\mathrm{F}=12.734, \mathrm{df}=899, \mathrm{p} \leq 0.000)$ during south-west monsoon. While, only $A$. gossypii population was significantly reduced after release of $R$. longifrons life stage during post-monsoon season $(\mathrm{F}=12.167, \mathrm{df}=$ $899, \mathrm{p} \leq 0.05)$.

In general, the release of $R$. longifrons in cotton fields was capable to reduce the populations of $H$. armigera (50\%), P. solenopsis (28\%), D. cingulatus (18.8\%), A. gossypii (11.8\%) during south-west monsoon season (Fig. 2). However, during post-monsoon season, populations of $D$. cingulatus were reduced by $26 \%$, followed $P$. solenopsis (20.6\%) and A. gossypii (16.8\%).

Effect on natural enemies' populations. Other natural enemies like ants, coccinellids, wasps, other reduviids, and spiders were observed in the cotton fields. During the rainy season, the populations of reduviids $(\mathrm{F}=13.223, \mathrm{df}$ $=299, \mathrm{p} \leq 0.000)$, spiders $(\mathrm{F}=20.926, \mathrm{df}=299, \mathrm{p} \leq 0.000)$, and coccinellids $(\mathrm{F}=4.015, \mathrm{df}=299, \mathrm{p} \leq 0.05)$ had significantly increased in $R$. Longifrons-treated plots from the first and second releases respectively compared to control 


\begin{tabular}{|c|c|c|c|c|c|c|}
\hline \multirow[b]{2}{*}{ Number of releases } & \multirow[b]{2}{*}{ Seasons } & \multirow[b]{2}{*}{ Field treatment } & \multicolumn{4}{|c|}{ Predominant pests (mean number/plant \pm SE) } \\
\hline & & & A.gossypii & D. cingulatus & P. solenopsis & H. armigera \\
\hline \multirow{4}{*}{ First release } & \multirow{2}{*}{ S-WM } & Control & $112.81 \pm 5,74 \mathrm{a}$ & $1.13 \pm 0.18 \mathrm{a}$ & $6.63 \pm 0.82 \mathrm{a}$ & $0,19 \pm 0.04 \mathrm{a}$ \\
\hline & & R. longifrons release & $73.49 \pm 6.37 \mathrm{~b}$ & $2.00 \pm 0.39 \mathrm{a}$ & $1.56 \pm 0.33 \mathrm{~b}$ & $0.00 \pm 0.00 \mathrm{~b}$ \\
\hline & \multirow{2}{*}{ P-M } & Control & $74.79 \pm 3.81 \mathrm{a}$ & - & $12.71 \pm 2.09 \mathrm{a}$ & - \\
\hline & & R. longifrons release & $51.54 \pm 3.14 \mathrm{~b}$ & - & $7.25 \pm 0.76 \mathrm{a}$ & - \\
\hline \multirow{4}{*}{ Second release } & \multirow{2}{*}{ S-WM } & Control & $98.35 \pm 5.62 \mathrm{a}$ & $0.15 \pm 0.04 \mathrm{a}$ & $0.96 \pm 0.21 \mathrm{a}$ & $0.01 \pm 0.00 \mathrm{a}$ \\
\hline & & R. longifrons release & $72.52 \pm 3.16 \mathrm{~b}$ & $0.11 \pm 0.03 \mathrm{a}$ & $0.45 \pm 0.11 \mathrm{a}$ & $0.01 \pm 0.00 \mathrm{a}$ \\
\hline & \multirow{2}{*}{$\mathrm{P}-\mathrm{M}$} & Control & $46.19 \pm 2.55 \mathrm{a}$ & - & $8.86 \pm 1.11 \mathrm{a}$ & - \\
\hline & & R. longifrons release & $46.64 \pm 2.15 \mathrm{a}$ & - & $7.85 \pm 0.82 \mathrm{a}$ & - \\
\hline \multirow{4}{*}{ Third release } & \multirow{2}{*}{ S-WM } & Control & $78.77 \pm 3.15 \mathrm{a}$ & $0.17 \pm 0.04 \mathrm{a}$ & $7.65 \pm 1.47 \mathrm{a}$ & - \\
\hline & & R. longifrons release & $68.13 \pm 2.92 \mathrm{a}$ & $0.05 \pm 0.02 \mathrm{~b}$ & $7.93 \pm 1.51 \mathrm{a}$ & - \\
\hline & \multirow{2}{*}{ P-M } & Control & $36.85 \pm 1.93 \mathrm{a}$ & $0.17 \pm 0.07 \mathrm{a}$ & $9.09 \pm 0.91 \mathrm{a}$ & - \\
\hline & & R. longifrons release & $30.25 \pm 1.81 \mathrm{~b}$ & $0.08 \pm 0.05 a$ & $9.38 \pm 0.84 \mathrm{a}$ & - \\
\hline \multirow{4}{*}{ Total mean population after release } & \multirow{2}{*}{ S-WM } & Control & $96.64 \pm 2.94 \mathrm{a}$ & $0.72 \pm 0.13 \mathrm{a}$ & $5.08 \pm 0.58 \mathrm{a}$ & $0.06 \pm 0.01 \mathrm{a}$ \\
\hline & & R. longifrons release & $71.38 \pm 2.55 \mathrm{~b}$ & $0.48 \pm 0.06 \mathrm{a}$ & $3.31 \pm 0.54 \mathrm{~b}$ & $0.00 \pm 0.00 \mathrm{~b}$ \\
\hline & \multirow{2}{*}{ P-M } & Control & $52.61 \pm 1.81 \mathrm{a}$ & $0.06 \pm 0.02 \mathrm{a}$ & $10.22 \pm 0.85 \mathrm{a}$ & - \\
\hline & & R. longifrons release & $42.81 \pm 1.48 \mathrm{~b}$ & $0.03 \pm 0.01 \mathrm{a}$ & $8.16 \pm 0.47 \mathrm{a}$ & - \\
\hline
\end{tabular}

Table 3. Effect of augmentative releases of Rhynocoris longifrons life stages on the four predominant pest in the cotton fields during South-west monsoon (S-WM, July to September 2011) and Post-monsoon season (P-M, December to February 2011-12) at Virudhunagar and Tuticorin districts respectively. Means followed by different letters in a column for each release and season or the total mean population are significantly different (SNK test, $\mathrm{P}<0.05)$.

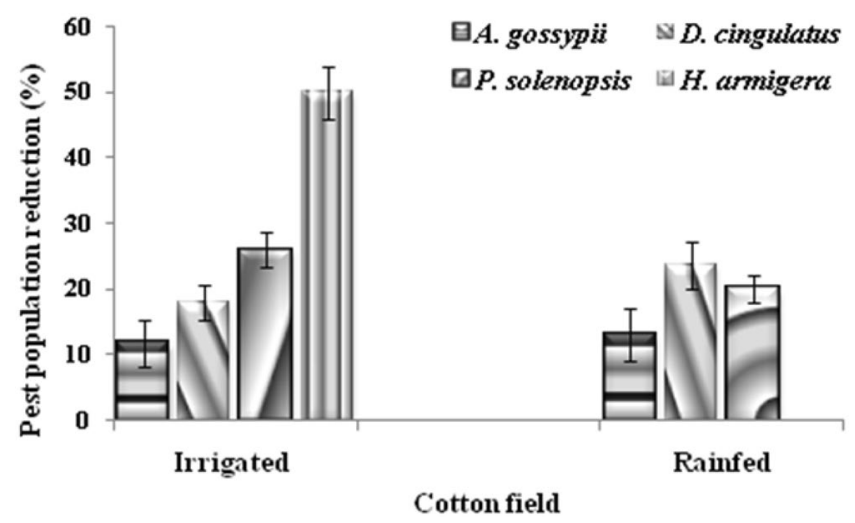

Figure 2. Augmentative releases of $R$. longifrons on the natural enemies population (number/plant) under rainfed condition. Plots without reduviid predator (A) and Plots without reduviid predator (B).

(Table 4). However, a significant reduction of ants $(\mathrm{F}=4.056, \mathrm{df}=299, \mathrm{p} \leq 0.05)$ and wasps $(\mathrm{F}=5.279, \mathrm{df}=299$, $\mathrm{p} \leq 0.05)$ populations was observed after the second release of $R$. longifrons life stages. Similar trend was also observed during post-monsoon season where significant reduction of ants $(\mathrm{F}=4.983, \mathrm{df}=299, \mathrm{p} \leq 0.05)$ and wasps $(\mathrm{F}=4.388$, $\mathrm{df}=299, \mathrm{p} \leq 0.05)$ populations was observed after the third release of $R$. longifrons life stages.

When we considered the total mean population after the three releases, there were significant increasing in the population of coccinellids $(\mathrm{F}=3.906, \mathrm{df}=899, \mathrm{p} \leq 0.05)$, reduviids $(\mathrm{F}=14.206, \mathrm{df}=899, \mathrm{p} \leq 0.000)$ and, spiders $(\mathrm{F}=8.171, \mathrm{df}=899, \mathrm{p} \leq 0.05)$ compared with the control plots during south-west monsoon. It is the same trends for the reduviids populations $(\mathrm{F}=14.764, \mathrm{df}=899, \mathrm{p} \leq 0.000)$ during post-monsoon season (Table 4). However, ants populations were significantly reduced as well during south-west monsoon $(\mathrm{F}=5.403, \mathrm{df}=899, \mathrm{p} \leq 0.05)$ than post-monsoon seasons $(\mathrm{F}=5.700, \mathrm{df}=899, \mathrm{p} \leq 0.05)$ in $R$. longifrons treated plots.

Cotton production, Cost Benefit Ratio (CBR) and Percent avoidable loss. Cotton production was higher in the predator-release plots $\left(837.0\right.$ and $753.4 \mathrm{~kg} / \mathrm{Hectare}^{-1}$ for south-west monsoon and post-monsoon seasons respectively). Similarly, the cost benefit ratio was higher in the predator-release treatment (1:1.28) than in the control treatment (1:1.17) during the south-west monsoon season, as well as post-monsoon (Table 5). Cost of cultivation was less in the control [= 4872.0 (73,08 US Dollar) and 26652.0 (399,78 US Dollar) for South-west monsoon and post-monsoon seasons respectively)] compared with the predator-released field $[=29096.0$ (436,44 US Dollar) and 28134.0 (422,01 US Dollar), for South-west monsoon and post-monsoon seasons respectively)]. A higher PAL was recorded in the South-west monsoon season (14.5\%) than in the post-monsoon season (4.9\%) (Table 5). 


\begin{tabular}{|c|c|c|c|c|c|c|c|}
\hline \multirow[b]{2}{*}{ Number of releases } & \multirow[b]{2}{*}{ Seasons } & \multirow[b]{2}{*}{ Field treatment } & \multicolumn{5}{|c|}{ Mean number \pm SE of natural enemies/plant } \\
\hline & & & Coccinellids & Ants & Reduviids & Spiders & Wasps \\
\hline \multirow{4}{*}{ First release } & \multirow{2}{*}{ S-WM } & Control & $0.23 \pm 0.05 \mathrm{a}$ & $0.67 \pm 0.10 \mathrm{a}$ & $0.00 \pm 0.00 \mathrm{~b}$ & $0.09 \pm 0.04 \mathrm{~b}$ & $0.07 \pm 0.02 \mathrm{a}$ \\
\hline & & R. longifrons release & $0.24 \pm 0.05 \mathrm{a}$ & $0.25 \pm 0.06 \mathrm{~b}$ & $0.12 \pm 0.03 \mathrm{a}$ & $0.45 \pm 0.08 \mathrm{a}$ & $0.09 \pm 0.02 \mathrm{a}$ \\
\hline & \multirow{2}{*}{ P-M } & Control & $0.45 \pm 0.06 \mathrm{a}$ & $0.86 \pm 0.13 a$ & $0.00 \pm 0.00 \mathrm{~b}$ & $0.11 \pm 0.28 \mathrm{a}$ & $0.09 \pm 0.02 \mathrm{a}$ \\
\hline & & R. longifrons release & $0.31 \pm 0.02 \mathrm{a}$ & $0.60 \pm 0.11 \mathrm{a}$ & $0.27 \pm 0.08 \mathrm{a}$ & $0.12 \pm 0.02 \mathrm{a}$ & $0.10 \pm 0.03 \mathrm{a}$ \\
\hline \multirow{4}{*}{ Second release } & \multirow{2}{*}{ S-WM } & Control & $0.27 \pm 0.04 \mathrm{~b}$ & $0.40 \pm 0.06 \mathrm{a}$ & $0.01 \pm 0.01 \mathrm{a}$ & $0.21 \pm 0.03 \mathrm{a}$ & $0.33 \pm 0.04 \mathrm{a}$ \\
\hline & & R. longifrons release & $0.38 \pm 0.04 \mathrm{a}$ & $0.27 \pm 0.04 \mathrm{~b}$ & $0.04 \pm 0.02 \mathrm{a}$ & $0.24 \pm 0.01 \mathrm{a}$ & $0.21 \pm 0.03 \mathrm{~b}$ \\
\hline & \multirow{2}{*}{$\mathrm{P}-\mathrm{M}$} & Control & $0.31 \pm 0.01 \mathrm{a}$ & $0.64 \pm 0.13 \mathrm{a}$ & $0.00 \pm 0.00 \mathrm{a}$ & $0.12 \pm 0.03 \mathrm{a}$ & $0.04 \pm 0.01 \mathrm{a}$ \\
\hline & & R. longifrons release & $0.19 \pm 0.04 \mathrm{a}$ & $0.53 \pm 0.10 \mathrm{a}$ & $0.01 \pm 0.00 \mathrm{a}$ & $0.08 \pm 0.02 \mathrm{a}$ & $0.03 \pm 0.15 \mathrm{a}$ \\
\hline \multirow{4}{*}{ Third release } & \multirow{2}{*}{ S-WM } & Control & $0.44 \pm 0.05 \mathrm{a}$ & $0.70 \pm 0.06 \mathrm{a}$ & $0.01 \pm 0.01 \mathrm{a}$ & $0.40 \pm 0.04 \mathrm{a}$ & $0.26 \pm 0.04 \mathrm{a}$ \\
\hline & & R. longifrons release & $0.53 \pm 0.01 \mathrm{a}$ & $0.89 \pm 0.07 \mathrm{a}$ & $0.03 \pm 0.01 \mathrm{a}$ & $0.41 \pm 0.04 \mathrm{a}$ & $0.27 \pm 0.03 \mathrm{a}$ \\
\hline & \multirow{2}{*}{ P-M } & Control & $0.32 \pm 0.04 \mathrm{a}$ & $0.68 \pm 0.09 a$ & $0.00 \pm 0.00 \mathrm{a}$ & $0.21 \pm 0.04 \mathrm{a}$ & $0.14 \pm 0.03 a$ \\
\hline & & R. longifrons release & $0.33 \pm 0.05 a$ & $0.46 \pm 0.07 \mathrm{~b}$ & $0.01 \pm 0.00 \mathrm{a}$ & $0.13 \pm 0.02 \mathrm{a}$ & $0.07 \pm 0.02 \mathrm{~b}$ \\
\hline \multirow{4}{*}{$\begin{array}{l}\text { Total mean population } \\
\text { after release }\end{array}$} & \multirow{2}{*}{ S-WM } & Control & $0.32 \pm 0.35 \mathrm{~b}$ & $0.59 \pm 0.04 a$ & $0.01 \pm 0.04 \mathrm{~b}$ & $0.23 \pm 0.02 \mathrm{~b}$ & $0.18 \pm 0.01 \mathrm{a}$ \\
\hline & & R. longifrons release & $0.38 \pm 0.30 \mathrm{a}$ & $0.47 \pm 0.38 \mathrm{~b}$ & $0.06 \pm 0.01 \mathrm{a}$ & $0.38 \pm 0.03 \mathrm{a}$ & $0.23 \pm 0.02 \mathrm{a}$ \\
\hline & \multirow{2}{*}{ P-M } & Control & $0.36 \pm 0.03 a$ & $0.73 \pm 0.07 \mathrm{a}$ & $0.00 \pm 0.00 \mathrm{~b}$ & $0.15 \pm 0.02 \mathrm{a}$ & $0.09 \pm 0.01 \mathrm{a}$ \\
\hline & & R. longifrons release & $0.28 \pm 0.03 \mathrm{a}$ & $0.53 \pm 0.05 \mathrm{~b}$ & $0.09 \pm 0.03 \mathrm{a}$ & $0.11 \pm 0.01 \mathrm{a}$ & $0.07 \pm 0.01 \mathrm{a}$ \\
\hline
\end{tabular}

Table 4. Effect of augmentative releases of Rhynocoris longifrons life stages on natural enemies' population in the cotton fieldsduring South-west monsoon (S-WM, July to September 2011) and Post-monsoon season (P-M, December to February 2011-12) at Virudhunagar and Tuticorin districts respectively. Means followed by different letters in a column for each release and season or the total mean population are significantly different (SNK test, $\mathrm{P}<0.05$ ).

\section{Discussion}

Reduviids are distributed in cotton agro-ecosystems worldwide and considered as important biocontrol agents ${ }^{10}$. Hence, use of reduviid predators to manage cotton pests can be one of the effective components of IPM programme, thus basic information is needed about hiding behavior, predatory potential, and other factors. The present study clearly shows that $R$. longifrons hide under different objects and, the preference for an object is function of the time of the day. The reduviid predator Rhynocoris fuscipes (Fabricius) also showed similar hiding behavior $^{31}$. This hiding behavior is an advantageous in the framework of an IPM because it allows this predator to better surprise the prey it captures. Moreover, it allows a better escaping from their natural enemies such spiders and wasps ${ }^{31-33}$. Therefore, we can conclude that $R$. longifrons nymphs and adults can survive and adapt in the cotton agro-ecosystem after its release.

Our results showed that, feeding potential of $R$. longifrons life stages on P. solenopsis and A. gossypii adults, $D$. cingulatus nymphs, and $H$. armigera larvae had not varied in relation to day and night hours. This result was surprising because some authors suggested that reduviid predators are either nocturnal or diurnal ${ }^{34}$. For example, Lira et al. ${ }^{35}$ found immature Harpactorini assassin bug feeding on a scorpion during the night time only. In contrast, Sycanus sp. and Scipinia sp. life stages were more active in the morning (6.30 to 10.0 a.m. $)^{36}$. Our results imply that $R$. longifrons life stages can be released at any time of the day and we recommend the release of the predator third-stadium for A. gossypii control in screen house.

The predominance of $A$. gossypii and $P$. solenopsis populations in cotton fields respectively during south-west and post-monsoon seasons are not surprising. In fact, it is known that the population dynamics of aphids and mealybugs can be affected by seasonal changes in weather conditions ${ }^{37}$. Moreover, Wang et al. ${ }^{38}$ showed that high rainfall was unfavourable for serious infestation by P. solenopsis. Our study showed that, augmentative releases of $R$. longifrons significantly reduced the number of insect pests in the cotton fields. The first release of this predator in cotton fields was capable to reduce A. gossypii and P. solenopsis populations during south-west and post monsoon compared with the control. Similarly, the field release of some reduviid predators such as Pristhesancus plagipennis Walker ${ }^{17,39}$, Platymeris laevicollis Distant ${ }^{40}$ and Rhynocoris marginatus (Fab. ${ }^{19,20}$ were successful in reducing various pests in coconut palm, cotton and groundnut fields. Our results showed that $R$. longifrons can be an effective predator of multiple preys, which is consistent with previous results for generalist predators ${ }^{9,41,42}$.

Further, no adverse interaction between $R$. longifrons and indigenous predators like coccinellids, spiders and, other reduviids were observed. This situation suggests reduviid predators do not interfere with other natural enemies. Consequently, reduviid predator may be an ecofriendly protection for cotton pest populations and are likely to be highly detrimental to their biological control. Reduviids can be utilized as part of a multiple species release program as suggested for Dephastus catalinae (Horn) (Coleoptera: Coccinellidae ${ }^{43}$. However, Symondson et al. ${ }^{44}$ reported that at natural ecosystems, change of biotic and abiotic variables is common and that under such circumstance, it was difficult to predict the interspecific and intraspecific interactions between released generalist predators, and the predators dwelled in the eco-system. The decrease of ants in R. longifrons treated plots could be explained among other factors, by the decrease of aphids and mealybugs populations, which bribe them with their honeydew excretion. In fact, it is known that $P$. solenopsis ${ }^{45}$ and, $A$. gossypii ${ }^{46}$ present a mutualism association with ants. 


\begin{tabular}{|l|l|l|l|l|}
\hline \multirow{2}{*}{ Expenses (in US dollar) } & \multicolumn{3}{l}{ Field conditions } \\
\cline { 2 - 5 } & \multicolumn{2}{|l|}{ Irrigated condition } & \multicolumn{2}{l|}{ Rain fed condition } \\
\cline { 2 - 5 } & Treatment & Control & Treatment & Control \\
\hline Plough & 54.07 & 54.07 & 36.06 & 36.06 \\
\hline Sowing & 29.68 & 29.68 & 25.23 & 25.23 \\
\hline Manure & 84.28 & 84.28 & 45.05 & 45.05 \\
\hline Harvesting & 55.46 & 55.46 & 54.07 & 54.07 \\
\hline Transportation & - & - & 58.05 & 58.05 \\
\hline Weeding & 86.51 & 86.51 & 90.11 & 90.11 \\
\hline $\begin{array}{l}\text { Cost of cultivation in } R . \\
\text { longifrons }\end{array}$ & 21.07 & - & 21.07 & - \\
\hline Total expenses & 331.07 & 310.00 & 329.64 & 308.56 \\
\hline Total Income & 424.61 & 362.97 & 410.57 & 388.95 \\
\hline Cotton production $\left(\mathrm{Kg} / \mathrm{h}^{-1}\right)$ & 837.0 & 715.5 & 753.35 & 716.30 \\
\hline Cost Benefit Ratio $(\mathrm{CBR})$ & 1.28 & 1.17 & 1.24 & 1.26 \\
\hline The percent avoidable loss $(\%)$ & 14.5 & & 4.9 & \\
\hline
\end{tabular}

Table 5. Augmentative release of $R$. longifrons on cost benefit ratio analysis under irrigated and rainfed cotton cultivation.

Comparatively of the cotton production $(1585 \mathrm{~kg} / \mathrm{ha})$ at Tamil Nadu of India, the yield recorded during our study in cotton fields during south-west monsoon $(2068 \mathrm{~kg} / \mathrm{ha})$ and post-monsoon season $(1862 \mathrm{~kg} / \mathrm{ha}) \mathrm{reveal}$ that release of reduviids reduced impact of insect pests thus enhance cotton production. Similar trends were also observed when $P$. plagipennis was release in cotton fields ${ }^{17,39}$. Although the cost benefit ratio was low (1:1.28 or 1:1.24) comparatively to entomopathogenic insecticides such as HaNPV (1:3.50) or Bt (1:1.23) used for cotton protection $^{47,48}$, it had been higher than those of control highlighting the benefit of integrating this predator in cotton pest management. Furthermore, the small-scale mass production technology for $R$. longifrons developed by Sahayaraj and $\mathrm{Ravi}^{49}$ is available for an augmentative biological control program. In view of these encouraging results, it would be interesting in the framework of a biocontrol of cotton pests program to integrate this predator in other agro-climatic zones in Tamil Nadu as well as in other states in India.

\section{Conclusion}

Based on the observed hiding behaviour of $R$. longifrons, we conclude that this predator can survive and adapt to the cotton agro-ecosystem after its release. In the framework of an IPM program, $R$. longifrons life stages can be releases at any time of the day. Augmentative releases of this predator reduced significantly the number of insect pests in the cotton fields. $R$. longifrons increased the cotton production and enhanced the cost benefit ratio increased in predator released cotton field. It is concluded that reduviid predators can be integrated into cotton integrated pest management program.

\section{Methods}

Collection and maintenance of insects. Life stages of $R$. longifrons were collected from cotton fields ( 2 females, 1 male, 5 nymphs) and scrub jungle ( 3 females, 2 males, and 8 nymphs) bordering agro-ecosystems $\left(8.7038^{\circ} \mathrm{N}, 770.8625^{\circ} \mathrm{E}\right)$ in Tirunelveli districts of Tamil Nadu, India. They were maintained on a factitious host, fourth and fifth instar Corcyra cephalonica (Stainton) (Lepidoptera: Pyralidae) under laboratory conditions at $30 \pm 2{ }^{\circ} \mathrm{C}, 61 \pm 5 \%$ relative humidity $(\mathrm{RH})$ and photoperiod of $11 \mathrm{~L}: 13 \mathrm{D} \mathrm{hr}$ in $1 \mathrm{~L}$ transparent plastic containers ( $15 \mathrm{~cm}$ diameter $\times 8 \mathrm{~cm}$ height) as described by Sahayaraj et al. (2002). Corcyra cephalonica eggs were purchased from the Agriculture Office, Palayamkottai, and maintained in $2 \mathrm{~L}$ plastic troughs $(20 \mathrm{~cm}$ diameter $\times 10 \mathrm{~cm}$ height $)$ on crushed wheat and groundnuts. For conducting various studies, $R$. longifrons life stages, third $(26.8 \pm 0.02 \mathrm{mg})$, fourth $(35.4 \pm 0.03 \mathrm{mg})$, fifth $(54.8 \pm 0.07 \mathrm{mg})$ nymphal instars, and adults (male $=67.8 \pm 0.08 \mathrm{mg}$, female $=$ $76.8 \pm 0.09 \mathrm{mg})$ were used.

Adults and immatures of the A. gossypii, P. solenopsis, D. cingulatus, and eggs and larvae of $H$. armigera were collected from cotton and maintained on their natural host plant under the above mentioned laboratory conditions. Life stages of $D$. cingulatus were maintained on wet cotton seeds. Both A. gossypii and P. solenopsis life stages were maintained on cotton seedlings (5-10 days old) which were established in small plastic tubs $(10 \mathrm{~cm}$ height $\times 8 \mathrm{~cm}$ upper diameter $\times 6 \mathrm{~cm}$ lower diameter). On each seedling 40-50 D. cingulatus nymphs or adults were accommodated. $H$. armigera larvae were maintained individually in plastic containers $(8 \times 6.5 \mathrm{~cm})$ with a mixture of healthy cotton flowers, flower buds and young leaves.

Hiding behaviour of the predator inside the screen houses. To record the hiding places of the predator when it was released in cotton during an augmentative pest management programme, the methodology described by Tomson et al. ${ }^{31}$ was used. Observations of hiding behaviour of $R$. longifrons were carried out in a screen house $(12 \mathrm{~m}$ length $\times 7.8 \mathrm{~m}$ width) using 30 day-old cotton plants (variety: MCU-5). The plot consisted of 52 plants ( 4 column $\times 13$ rows) with inter-plant spacing of $0.60 \mathrm{~m}$ and inter-row distances of $0.75 \mathrm{~m}$, oriented east to west. Before releasing the different life stages of the $R$. longifrons, the cotton plants, fallen leaves, pebbles, and other objects found in the plots were checked thoroughly to confirm the absence of any reduviids. Then, 10 fourth 
instar predators (previously starved for $24 \mathrm{hr}$ ) were released at 6.00 a.m., 8.30 a.m., 11.00 a.m. and 3.30 p.m in different pots. The reduviids were introduced individually by means of a camel's hair brush into the northeast corner of the base of the plant. Two hours after every release, the percentage of insects that settled at various places [cotton plant, fallen leaves, small pebbles in the plant and other objects (soil balls, weed plants)] were recorded. Similar procedure was followed for the fifth instars and adult predators.

Biocontrol potential of $\boldsymbol{R}$. longifrons in relation to day and night hours. Modified methodology of Tomson et al. ${ }^{31}$ was followed for bioefficacy experiments. For the experiments, cotton seeds of MCU-5 variety were sown in cement pots $(36 \times 30 \times 22 \mathrm{~cm})$ and maintained in screen house at St. Xavier's College, Palayamkottai. The bioefficacy of $R$. longifrons life stages (third, fourth and fifth instar nymphs and adults) was tested against preferred life stages of $A$. gossypii (4 adults/predator), D. cingulatus (second and third nymphal instars, 2 of each instar/predator), $H$. armigera (second and third instar larva, 2 of each instar/predator) and $P$. solenopsis (4 adults/predator). The predatory potential of $R$. longifrons was evaluated between 6 a.m. and 6 p.m. (day experiments) and between 6 p.m. and 6 a.m. (night experiments). pests were released on the 25-30-day old cotton plants covered by a nylon net at 6 a.m. for day or 6 p.m for night experiments respectively. One hour after pests release, 24-hour pre-starved $R$. longifrons (third, fourth and fifth instar nymphs, and adults - 2/plant) were introduced separately on the infested cotton plants. Six replications were used for each pest and predator life stage for both experiments. Three replications without predator were established as control. After $12 \mathrm{~h}$, the number of live and dead preys in each plant was counted and predation rate of the $R$. longifrons life stages was calculated ${ }^{50}$.

Experimental design for the augmentative biocontrol potential evaluations. The augmentative biocontrol potential was evaluated during rain fed condition (South-west monsoon) 2011 (July to September) in the cotton field at Kothankulam $\left(9.4692^{\circ} \mathrm{N}, 77.6046^{\circ} \mathrm{E}\right)$, in the Virudhunagar district, Tamil Nadu and also in irrigated condition (post-monsoon season) 2011-2012 (December to February) at K. Duraisamiyapuram (E $77^{\circ} 35^{\circ}, \mathrm{N} 22.16^{\circ}$ ), in the Tuticorin district of Tamil Nadu. The methodology described by Tomson et al..$^{31}$ with slight modifications was used for these evaluations. For weed control and fertilization farmers' standard cultural practices were used to grow cotton (SVPR4 cultivar). Two treatments were evaluated, a cotton field into which $R$. longifrons was released and a control field, free of pesticides and predators. Unplanted buffer zone ( $2 \mathrm{~m})$ was established between treatment and control plots. The treatment plots were arranged in randomized complete block design with five replications ( 10 plots total with a size of $10 \mathrm{~m} \times 5 \mathrm{~m}$ each). To identify the predominant pests and predators in experimental cotton fields, we examined in each field 8-10 leaves of 10-randomly selected plants from two days before predators release. $R$. longifrons nymphal instars ( 50 individuals each) were released individually during 6-8 a.m. in each experimental cotton fields 40, 55 and 70 days after the seedling emergence (ASE). In addition, three cards $(3 \times 3 \mathrm{~cm})$ containing each 50 eggs of $R$. longifrons were also placed onto the twigs of a plant in each cotton field. In total, a mixture of 900 R. longifrons ( 150 eggs, 250 nymphal instars $\times 3$ releases $=$ $900 /$ plot) were released in each plot. Three days after the predators' release, 10 randomly selected cotton plants in each experimental cotton field were visually examined for the presence of $A$. gossypii, D. cingulatus, P. solenopsis and $H$. armigera. The number of each species of predators encountered was also recorded per plant.

Cost Benefit Ratio (CBR) and Percent Avoidable loss. At the completion of the growing seasons, the cotton in each plot was harvested. It was then cleaned, weighed and sold in the local market. The cost benefit ratio (CBR) was calculated based on the income per hectare thus generated. In addition, the percent of avoidable loss (PAL) was also calculated according to the method proposed by Krishnaiah ${ }^{51}$.

Statistical analysis. Before variance analysis, the data normality was tested using Levene's test. Data on the percentage of predator hiding under various objects in relation to life stages was subjected to arcsine transformation, while the total number of prey consumed by a predator in $24 \mathrm{~h}$, numbers of different insect pests and natural enemies present at each release (first, second and third), as well as their total mean populations were log-transformed to homogenize the variances before being subjected to variance analysis using IBM SPSS Statistics version 25 software package. Significant differences between the means were separated using the Student Newman Keuls test $(\mathrm{p} \leq 0.05)$. Original means are presented in tables and figures.

Received: 10 September 2019; Accepted: 24 January 2020;

Published online: 20 April 2020

\section{References}

1. Lu, Z. Z. et al. Abundance of Aphis gossypii (Homoptera; Aphididae) and its main predators in organic and conventional cotton fields in north-west China. Ann. Appl. Biol. 66, 249-256 (2015).

2. Ehetisham-ul-Haq, M., Khan, M. A., Javed, M. T., Atiq, M. \& Rashid, A. Pathogenic aspects of Pantoea agglomerans in relation to cotton boll age and Dysdercus cingulatus (Fabricius) transmitting seed and boll rot in cotton germplasm. Archives Phytopathol. Plant Pro. 47, 1815-1826 (2014).

3. El-Zahi, E. S., Aref, S. A. E. \& Korish, S. K. M. The cotton mealybug, Phenacoccus solenopsis Tinsley (Hemiptera: Pseudococcidae) as a new menace to cotton in Egypt and its chemical control. J. Plant Prot. Res. 56, 111-115 (2016).

4. Kriticos, D. J. et al. The Potential Distribution of Invading Helicoverpa armigera in North America: Is It Just a Matter of Time? PLoS ONE. 10, e0119618 (2015).

5. Joußen, N. \& Heckel, D.G. Resistance mechanisms of Helicoverpa armigera. In: Advances in Insect Control and Resistance Management. In Advances in Insect Control and Resistance Management (eds Horowitz, A. \& Ishaaya I.) 241-261 (Springer, Cham 2016).

6. Veettil, P. C., Krishna, V. V. \& Qaim, M. Ecosystem impacts of pesticide reductions through Bt cotton adoption. Aus. J. Agr. Res. Econ. 60, 1-20 (2016).

7. Lee, D. H., Short, B. D., Joseph, S. V., Bergh, J. C. \& Leskey, T. C. Review of the biology, ecology, and management of Halyomorpha halys (Hemiptera: Pentatomidae) in China, Japan, and the Republic of Korea. Environ. Entomol. 42, 627-641 (2013). 
8. Sahayaraj, K. Reduviids and their merits in biological control. In Basic and Applied Aspects of Biopesticides (ed Sahayaraj, K.) 195-214 (Springer India 2014).

9. Sahayaraj, K. \& Balasubramanian, R. Field Evaluation In Artificial Rearing of Reduviid Predators for Pest Management (eds Sahayaraj, K. \& Balasubramanian, R.) 147-165 (Springer Singapore 2016).

10. Kalidhas, S. \& Sahayaraj, K. Survey of reduviids in cotton agro-ecosystem of Tamil Nadu. Middle East. J. Sci. Res. 12, 1216-1223 (2012).

11. Shrestha, R. B. \& Parajulee, M. N. Potential cotton aphid, Aphis gossypii, population suppression by arthropod predators in upland cotton. Insect Sci. 20, 778-788 (2013).

12. Ricardo, A. P. \& Pratissoli, D. Biological control of agricultural pests: principles and field applications. Revista Ceres. 56, 410-419 (2009).

13. Van Lenteren, J. C. The state of commercial augmentative biological control: plenty of natural enemies, but a frustrating lack of uptake. Biol. Control. 57, 1-20 (2012).

14. Malaquias, J. B., Omoto, C., Ramalho, F. S., Wesley, W. A. C. \& Silveira, R. F. Bt cotton and the predator Podisus nigrispinus (Dallas) (Heteroptera: Pentatomidae) in the management of Spodoptera frugiperda (JE Smith) (Lepidoptera: Noctuidae) resistance to lambda-cyhalothrin. J. Pest Sci. 88, 57-63 (2015).

15. Sahayaraj, K. \& Ambrose, D. P. Field cage evaluation of the predator Ectomocoris tibialis Distant to control Dysdercus cingulatus Fab. J. Insect Sci. 10, 65-66 (1997).

16. Ambrose, D. P. \& Claver, M. A. Suppression of cotton leafworm Spodoptera litura, flower beetle Mylabris pustulata and red cotton bug Dysdercus cingulatus by Rhynocoris marginatus (Fab.) (Heteroptera: Reduviidae) in cotton field cages. J. App. Entomol. 123, 225-229 (1999).

17. Grundy, P. \& Maelzer, D. Assessment of Pristhesancus plagipennis (Walker) (Hemiptera: Reduviidae) as an augmented biological control in cotton and soybean crops. Aus. J. Entomol. 39, 305-309 (2000).

18. Claver, M. A. \& Ambrose, D. P. Evaluation of Rhynocoris kumarii Ambrose and Livingstone (Hemiptera: Reduviidae) as a potential predator of some lepidopteran pests of cotton. J. Biol. Cont. 15, 15-20 (2001).

19. Sahayaraj, K. \& Martin, P. Assessment of Rhynocoris marginatus (Fab.) (Hemiptera: Reduviidae) as augmented control in groundnut pests. J. Cent. Eur. Agr. 4, 103-110 (2003).

20. Sahayaraj, K. \& Ravi, C. Evaluation of reduviid predators and plant products against chosen groundnut pests. Archives of Phytopathol. Plant Prot. 40, 281-290 (2007).

21. Ambrose, D.P. \& Ganesh, K.A. Reduviid Predators. In Ecofriendly Pest Management for Food Security (Ed Omkar) 217-257 (Academic Press, 2016).

22. Sahayaraj, K., Kalidas, S. \& Tomson, M. Stage preference and functional response of Rhynocoris longifrons (Stål) (Hemiptera: Reduviidae) on three hemipteran cotton pests. Braz. Arch. Biol. Technol. 55, 733-740 (2012).

23. Claver, M. A., Ramasubbu, G., Ravichandran, B. \& Ambrose, D. P. Searching behaviour and functional response of Rhynocoris longifrons (Stål) (Heteroptera: Reduviidae), a key predator of pod sucking bug, Clavigralla gibbosa Spinola. Entomon. 27, 339-346 (2002).

24. Kumar, S. P., Kumar, A. G. \& Ambrose, D. P. Impact of intraspecific competition in the predation of Rhynocoris longifrons (Stål) (Hemiptera: Reduviidae) on Camponotine ant Camponotus compressus Fab. Hexapoda. 16, 1-4 (2009).

25. Weirauch, C. et al. An Illustrated Identifi cation Key to Assassin Bug Subfamilies and Tribes (Hemiptera: Reduviidae). Canadian J. Arth. 26, 1-115 (2014).

26. Sahayaraj, K., Ecological adaptive features of hunter reduviids (Insecta: Heteroptera: Reduviidae Latreille 1807) and their biological control potential. In Perspectives in Animal Ecology and Reproduction (eds Gupta, V.K. \& Verma, A.K.) 22-48 (Daya Publishing House, Delhi 2006).

27. Jackson, R. R., Salm, K. \& Nelson, X. J. Specialized prey selection behaviour of two East African assassin bugs, Scipinnia repax and Nagusta sp. that prey on social jumping spiders. J. Insect Sci. 10, 82, https://doi.org/10.1673/031.010.8201 (2010).

28. Ambrose, D. P., Kumar, S. P., Subbu, G. R. \& Claver, M. A. Biology and prey influence on the postembryonic development of Rhynocoris longifrons (St31) (Hemiptera: Reduviidae), a potential biological control agent. J. Biol. Control. 17, 113-119 (2003).

29. Sahayaraj, K. Pest control mechanism of reduviids (ed Sahayaraj, K) 222 p. (Oxford Book Company, India 2007).

30. Ambrose, D.P. Assassin bugs (ed Ambrose, D.P.) 310 p. (Science Pub Inc, India. 1999).

31. Tomson, M. et al. Mass rearing and augmentative biological control evaluation of Rhynocoris fuscipes (Hemiptera: Reduviidae) against multiple pests of cotton. Pest Mana. Sci. 73, 1743-1752 (2017).

32. Kimberly, G., Noma, S., Wilkinson, C. \& Kathy, W. S. Predation by spiders on periodical cicadas (Homoptera: Magicicada). J. Arachnol. 15, 277-279 (1987).

33. Timbilla, J.A. \& Braimah, H. Successful biological control of Chromolaena odorata in Ghana: the potential for a regional programme in Africa, in Proceedings of the Fifth International Workshop on Biological Control and Management of Chromolaena odorata (ed Zachariades, C., Muniappan, R., Strathie, L.W., Durban) 66-70 (South Africa, ARC-PPRI, Pretoria 2002).

34. Sahayaraj, K., Sundarapandiyan, N., Krishnaveni, C., Princy, R. J. \& Radhika, S. S. A. Laboratory culture of early life stages of Rhynocoris albopilosus (F.) (Hemiptera: Reduviidae) using early life stages of Eri silkworm (Lepidoptera: Saturniidae). Faunistic. Entomol. 68, 141-147 (2015).

35. Lira, A., Araujo, V. \& Albuquerque, C. Predation of a scorpion (Scorpiones: Buthidae) by an assassin bug (Heteroptera: Reduviidae) in the Brazilian Atlantic Forest. Turkish. J. Zool. 40, 294-296 (2016).

36. Winarsah, I.E. \& Hindayana, D. Populasi Reduviidae Pada Sawah Konvensional Dan Organik Di Desa Situ Gede, Kecamatan Bogor Barat, Bogor. (Bogor Agricultural University, http://repository.ipb.ac.id/handle/123456789/80777 (2014)

37. Fernandes, F. S. et al. Population dynamics of Aphis gossypii Glover and in sole and intercropping systems of cotton and cowpea. An. Acad. Bras. Ciênc. 90, 311-323 (2018).

38. Wang, Y., Watson, G. W. \& Zhang, R. The potential distribution of an invasive mealybug Phenacoccus solenopsis and its threat to cotton in Asia. Agr. Forest Entomol. 12, 403-416 (2010).

39. Grundy, P. R. Impact of low release rates of assassin bug Pristhesancus plagipennis (Walker) (Hemiptera: Reduviidae) on Helicoverpa spp. (Lepidoptera: Noctuidae) and Creontiades spp. (Hemiptera: Miridae) in cotton. Aus. J. Entomol. 43, 77-82 (2004).

40. Antony, M., Daniel, J., Kurian, C. \& Pillai, G. B. Attempts in introduction and colonization of the exotic reduviid predator, Platymeris lavecollis Distant for the biological suppression of the coconut rhinoceros beetle, Oryctes rhinoceros. Pro Plant Crops Symp. 2, 445-454 (1979).

41. Bueno, V. H. P. et al. New records of Tuta absoluta (Meyrick) (Lepidoptera: Gelechiidae) predation by Brazilian hemipteran predatory bugs. J. Appl. Entomol. 137, 29-34 (2013).

42. Pérez-Hedo, M. \& Urbaneja, A. Prospects for predatory mirid bugs as biocontrol agents of aphids in sweet peppers. J. Pest Scie. 88, 65-73 (2015)

43. Heinz, K. M., Brazzle, J. R., Parrella, P. M. \& Pickett, H. C. Field evaluation of augmentative releases of Dephastus catalinae (Horn) (Coleoptera: Coccinellidae) for suppression of Bemisia argentifolii Bellows and Perring (Homoptera: Aleyrodidae) infesting Cotton. Biol. Cont. 16, 241-251 (1999).

44. Symondson, W. O. C., Sunderland, K. D. \& Greenstone, M. H. Can generalist predators be effective biocontrol agents? Ann. Rev. Entomol. 47, 561-594 (2002). 
45. Tong, H.-J., Ao, Y., Li, Z.-H., Wang, Y. \& Jiang, M.-X. Invasion biology of the cotton mealybug, Phenacoccus solenopsis Tinsley: Current knowledge and future directions. J. Integr. Agric. 18, 758-770 (2019).

46. Kaplan, I. \& Eubanks, M. D. Disruption of Cotton Aphid (Homoptera: Aphididae)—Natural Enemy Dynamics by Red Imported Fire Ants (Hymenoptera: Formicidae). Environ. Entomol. 31, 1175-1183 (2002).

47. Praveen, P. M. \& Dhandapani, N. Ecofreindly management of major pests of okra Abelmoschus esculentus L. J. Veg. Crop Prod. 7, 3-12 (2001).

48. Balakrishnan, N., Basakaran, R.K.M. \& Mahadevan, N.R. Evaluation of different IPM modules on the effective management of sucking pests of cotton under rainfed condition. Pro. Int. Sym. Strategies for sustainable cotton production-A Global Vision, Crop Protection, UAS, Dharwad, Karnataka, India. 254-257 (2004).

49. Sahayaraj, K. \& Ravi, C. Small-scale Mass Production Strategy for a Reduviid Predator Rhynocoris longifrons Stal (Heteroptera: Reduviidae). Perspectives in Ani Ecol Repro. 4, 53 (2002).

50. Majesh Tomson, $\mathrm{K}$ et al. Mass rearing and augmentative biological control evaluation of Rhynocoris fuscipes (Hemiptera: Reduviidae) against multiple pests of cotton Pest Manag Sci https://doi.org/10.1002/ps.4532 (2017).

51. Krishnaiah, K. Methodology for assessing crop losses due to the pest of vegetables. In Assessment of crop losses due to the pest and diseases, (eds Govindu, H.C., Veeresh, G.K., Walker, P.T., Jenkyn, J.F.), 259-267 (UAS tech. Series No. 33. University of Agricultural Sciences, Hebbal, Bangalore, 1977).

\section{Acknowledgements}

Authors are thankful to the Council for Scientific and Industrial Research, Govt. of India (37/1043/08/EMR II), for funding to Sahayaraj. Authors are gratefully than the Authorities of St. Xavier's College, Palayamkottai for providing the necessary laboratory and field facilities.

\section{Author contributions}

K.S. and S.K. designed the work and analyses the data, S.K. executed the work and made rough version, K.S. and L.Y.L.E. corrected first and second version of the work.

\section{Competing interests}

The authors declare no competing interests.

\section{Additional information}

Correspondence and requests for materials should be addressed to K.S.

Reprints and permissions information is available at www.nature.com/reprints.

Publisher's note Springer Nature remains neutral with regard to jurisdictional claims in published maps and institutional affiliations.

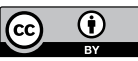

Open Access This article is licensed under a Creative Commons Attribution 4.0 International License, which permits use, sharing, adaptation, distribution and reproduction in any medium or format, as long as you give appropriate credit to the original author(s) and the source, provide a link to the Creative Commons license, and indicate if changes were made. The images or other third party material in this article are included in the article's Creative Commons license, unless indicated otherwise in a credit line to the material. If material is not included in the article's Creative Commons license and your intended use is not permitted by statutory regulation or exceeds the permitted use, you will need to obtain permission directly from the copyright holder. To view a copy of this license, visit http://creativecommons.org/licenses/by/4.0/.

(c) The Author(s) 2020 